\title{
Risks of Infection with SARS-CoV-2 Due to Contaminated Surfaces: A Scoping Review
}

\author{
Marjan Mohamadi ${ }^{1}$, Awa Babington-Ashaye ${ }^{1, * \mathbb{D}}$, Agnès Lefort ${ }^{2}$ and Antoine Flahault ${ }^{1}$ \\ 1 Faculty of Medicine, Institute of Global Health, University of Geneva, 1202 Geneva, Switzerland; \\ Marjan.mohamadi@etu.unige.ch (M.M.); antoine.flahault@unige.ch (A.F.) \\ 2 Service de Médecine Interne, Hôpital Beaujon, Clichy and IAME, UMR1137, INSERM and Université de Paris, \\ 75006 Paris, France; Agnes.lefort@aphp.fr \\ * Correspondence: Awa.c.sarr@gmail.com or awa.sarr@etu.unige.ch; Tel.: +41-79-828-07-55
}

check for

updates

Citation: Mohamadi, M.;

Babington-Ashaye, A.; Lefort, A.;

Flahault, A. Risks of Infection with

SARS-CoV-2 Due to Contaminated

Surfaces: A Scoping Review. Int. J. Environ. Res. Public Health 2021, 18 , 11019. https://doi.org/10.3390/ ijerph182111019

Academic Editors: Marcello Covino and Paul B. Tchounwou

Received: 17 August 2021

Accepted: 14 October 2021

Published: 20 October 2021

Publisher's Note: MDPI stays neutral with regard to jurisdictional claims in published maps and institutional affiliations.

Copyright: (c) 2021 by the authors. Licensee MDPI, Basel, Switzerland. This article is an open access article distributed under the terms and conditions of the Creative Commons Attribution (CC BY) license (https:// creativecommons.org/licenses/by/ $4.0 /)$.

\begin{abstract}
The COVID-19 outbreak is a global health concern. Understanding the transmission modes of the SARS-CoV-2 virus is key to limit the spread of the pandemic. A lack of knowledge about the possibility of SARS-CoV-2 transmission and infection through contaminated surfaces is noticeable and recent studies have stated conflicting findings. This scoping review aims to understand the risks of contaminations via fomites better. Relevant publications were selected through Google Scholar, Web of Science, PubMed, Embase, Medline, and Cochrane Library, with related keywords. PRISMA-ScR guidelines were followed. Out of the 565 articles found, exclusion criteria were applied, duplicates removed, and a total of 25 articles were finally included in the study. The included documents were assessed by the contamination risk: "low" (37.5\%), "high" (16.7\%), "plausible" $(8.3 \%)$, "unlikely" (8.3\%) risk, and "insufficient evidence" (29.2\%). Research in hospital settings was found as the main setting in the reviewed papers, which precisely indicated the risk of contaminated surfaces. This scoping review underscores the risk of SARS-CoV-2 infection via contaminated surfaces assessed as low in the majority of the reviewed articles. Further evaluation of the risk of the virus transmission by fomites and providing adequate information on its infectivity via contaminated surfaces in real-life conditions is essential.
\end{abstract}

Keywords: COVID-19; fomites; contaminated surfaces; transmission; SARS-CoV-2

\section{Introduction}

The coronavirus disease 2019 (COVID-19) outbreak is a global health concern [1], with an undoubtedly serious impact affecting people's lives in various aspects, including healthcare, economic, and social factors [2,3]. The novel coronavirus was firstly detected in Wuhan in December 2019 [4]. On 12 March 2020, due to the high infectivity of SARSCoV-2 [5] and numerous reported cases and deaths, the World Health Organization (WHO) declared the COVID-19 as a pandemic [6]. The virus SARS-CoV-2 belongs to the Coronaviridae family, some of whose viruses are associated with respiratory tract infections [7].

Understanding of the transmission modes of SARS-CoV-2 is a crucial matter. From a general perspective, the transmission of the respiratory virus has a few known routes, which are mainly (a) direct contact (person-to-person), (b) indirect contact by contaminated surfaces (fomites), and (c) airborne transmission by droplets or aerosols [8]. Based on the evidence to date, the transmission of SARS-CoV-2 is stated to be mostly airborne via droplets or aerosols through close contact with infected individuals $[9,10]$. However, other previous studies have suggested the possibility of hand to face transmission of pathogens by touching contaminated objects and surfaces, otherwise known as fomite transmission [11-16]. Moreover, face-touching behavior has been understood as a self-inoculation for microbial transmission $[11,12,17,18]$. In addition, some other studies underscore that contaminated surfaces could play a key role in the transmission of pathogens [13-16]. 
However, in the specific case of the SARS-CoV-2 virus, recent studies on the risk of fomites transmission have stated various findings. Most authors have demonstrated a low risk of contamination [11,19-21], while fewer authors suggested a higher risk [22,23].

For instance, as Kraay et al. stated, "while direct transmission is important, our model suggests that fomites can also transmit, which is important for exposures that are not in-person. Therefore, fomites transmission may be an important source of risk [22]". Another study emphasized a key role of fomites transmission, as "the results showed that moderate protein concentration in droplets markedly increased the infectivity of SARS$\mathrm{CoV}-2$, suggesting that a protein-rich medium like airway secretions could protect the virus when it is expelled and may enhance its persistence and transmission by contaminated fomites. Accordingly, it is plausible that fomites infected with SARS-CoV-2 play a key role in the indirect transmission of COVID-19 [24]."

However, Goldman believes that "the chance of transmission through inanimate surfaces is very small and only in instances where an infected person coughs or sneezes on the surface, and someone else touches that surface soon after they cough or sneeze (within 1-2 h) [19]. Another study has found that "despite prolonged viability of SARS-CoV-2 under laboratory-controlled conditions, uncultivable viral contamination of inanimate surfaces might suggest low feasibility for indirect fomite transmission [25]." In addition, findings from Moore et al. demonstrated that "the concentration of viral RNA was low and ranged from $<10$ to 460 genomic copies / $\mathrm{m} 3$ air. Infectious virus was not recovered from any of the PCR-positive samples analyzed." [26].

Therefore, in this present scoping review, we aim to provide a comprehensive overview of the literature about the risk of SARS-CoV-2 transmission via fomites in order to participate in a better understanding of relevant approaches to mitigate the propagation of the COVID-19 pandemic.

\section{Materials and Methods}

A scoping review of peer-reviewed and grey literature was conducted to identify the risks of infection with SARS-CoV-2 by contaminated surfaces.

A general literature search was first done on the SARS-CoV-2 virus to have a preliminary overview of the concepts and previous studies on this specific topic. Several studies on the SARS-CoV-2 virus were related to the risk of infection, such as contact and droplet transmission, airborne transmission, fomite transmission, and the possibility of transmission by animals. Importantly, this scoping review solely focused on resources related to the risks of infection with the SARS-CoV-2 due to contaminated surfaces. This review follows the framework of the Preferred Reporting Items for Systematic Review and Meta-analysis for Scoping Reviews (PRISMA-ScR) guideline.

\subsection{Search Strategy}

In order to broadly capture existing research on the defined topic, relevant publications were gathered using the search engines of Google Scholar, Web of Science, PubMed, Embase, Medline, and Cochrane Library.

Firstly, the search for the relevant literature was conducted using the following keywords in the titles of the articles: (SARS-CoV-2) OR (Novel Coronavirus) OR (COVID-19) AND (Fomites) OR (surface) OR (Inanimate surfaces) OR (Contaminated surfaces) OR (Environmental contamination) AND (Transmission) OR (Pathogen transmission) OR (Disease Transmission) AND (Viability) OR (Stability) OR (Survival) OR (Persistence).

The search was then broadened by including the 'Abstracts' in the search field. The methodology process used is summarized in Figure 1 (PRISMA flowchart).

Additionally, the search was also conducted by Mesh terms in PubMed as follows: (SARS-CoV-2) AND (Fomites) AND (Disease Transmission, Infectious) AND (Microbial viability) OR (Survival). The World Health Organization (WHO) and Centers for Disease Control and Prevention (CDC) websites were analyzed for relevant publications, which were considered as additional publications from other sources. 
In order to find potential additional relevant sources, identification and screening of further articles from references were undertaken. After completing the search with all relevant publications, duplicates were omitted.

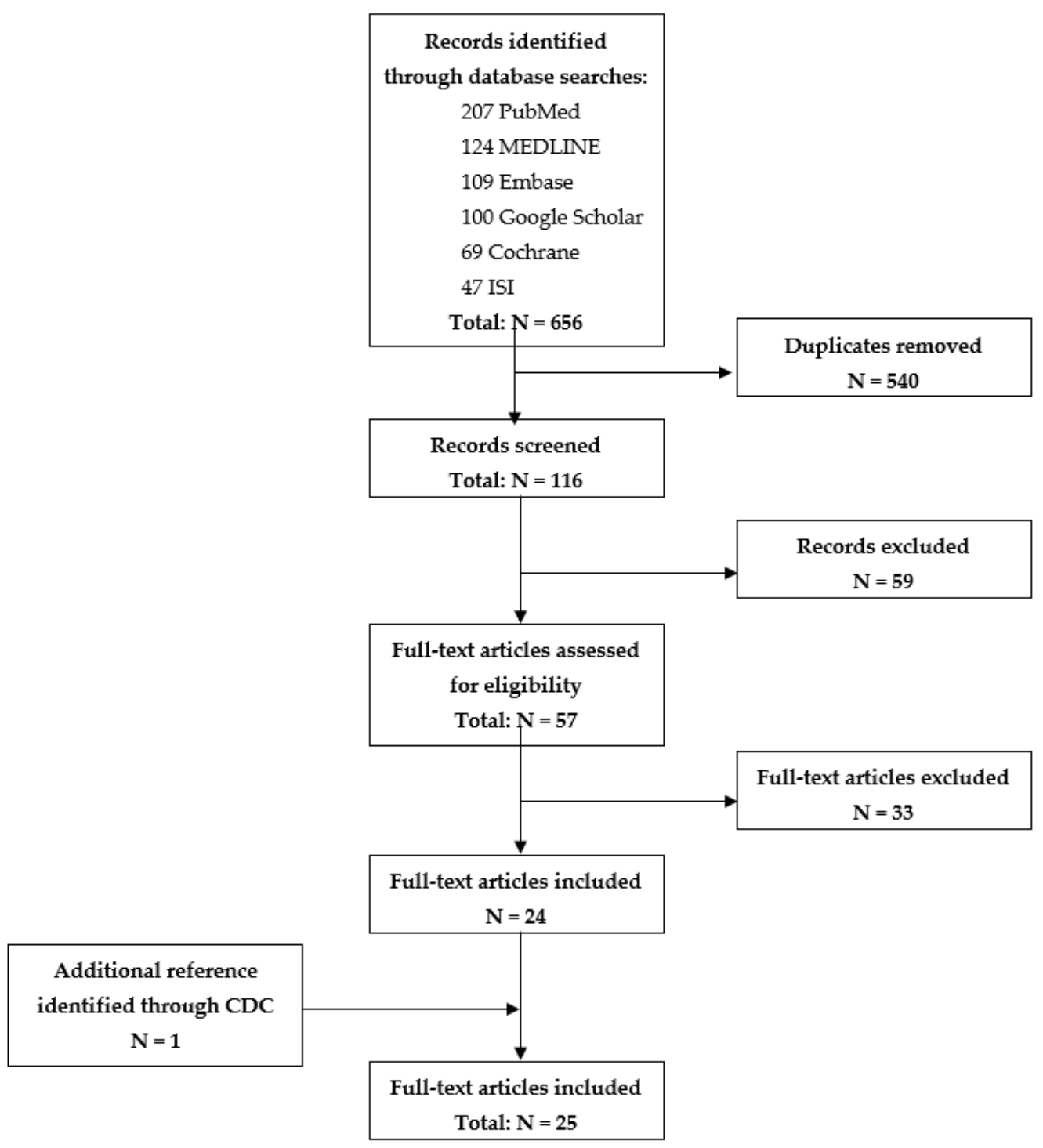

Figure 1. PRISMA flowchart.

\subsection{Inclusion and Exclusion Criteria}

The inclusion criteria were: (i) English-language publications related to the potential risks of infection by contaminated surfaces with the SARS-CoV-2 virus; (ii) all types of scientific publications such as editorials, viewpoints, articles, guidelines, etc., were included; (iii) any relevant settings such as fomites in hospitals, public places or in-house, for instance.

Exclusion criteria included publications related to other findings on COVID-19 disease and its clinical aspects or other routes of transmission of the virus, for instance, as examples. In addition, publications that did not imply a correlation between variables, such as the viral stability or virus load with the risk of infection, for example, were excluded.

\subsection{Data Extraction}

The relevant dataset was extracted and imported into an Excel extraction table by the main researcher (M.M.) This table includes the title, author(s), date of publication, study location focus, type of publication, the main topic, key findings, contamination risk assessment, and limits. The other co-authors screened publications to ensure their 
relevance and eligibility. The selected articles were imported by EndNote X7. The process of selection is reported in Figure 1.

\section{Results}

The search performed in the different databases underscores various interesting findings related to the risk of infection with SARS-CoV-2 from contaminated surfaces. The key results can be summarized as follow:

From the 25 documents selected for this review, 24 were retrieved through the database searches and 1 from the website of the CDC.

As mentioned in Figure 1, of a total of 565 publications found in the databases and SARS-CoV-2 source-related websites, 116 publications remained after removing the duplicates and then were screened by titles and abstracts. At this stage, 59 of the reviewed articles were classified as out of the scope of our research question and, therefore, were excluded. The full text of the remaining 57 publications was assessed, and 24 articles finally met the inclusion criteria.

Importantly, some excluded articles did not exactly state the risk of infection by fomites but had investigated some features of the virus that might lead to infectivity, but the relationship between those features and infectivity was not precisely discussed.

In addition, several excluded articles discussed the stability of the virus in different environmental conditions, but a lack of evidence on the relationship between the stability features and the risk of infection by contaminated surfaces was observed. Contrastingly, 17 articles from this category discussed a potential correlation and were included in our scoping review.

Five out of the 24 selected articles were surveyed in Europe, namely France, Switzerland, Germany, Italy, and England. Two of them were from the USA and one article, respectively, from Israel, China, and Singapore.

We could not identify a specific study setting in the remaining articles classified as Not Applicable, most of which were review articles and editorial letters. Articles since the beginning of the COVID-19 pandemic in early 2020 were assessed, and the last search was performed on 10 February 2021.

Amongst the included articles, ten out of 24 were review articles, which stated a clear conclusion about the risk of infection by fomites contaminated with SARS-CoV-2. Amongst the articles which have precisely indicated the risk of contaminated surfaces with SARS-CoV-2, five of them performed the research in hospital settings, three of them in community settings including schools, offices and high-touch surfaces in a city, one in a laboratory environment, and finally one in a quarantine household.

Appendix Tables A1-A3 summarize the main features of the included publications.

Based on our review, the main topics of the relevant publications found were: (I) persistence of the SARS-CoV-2 on fomites or inanimate surfaces, (II) risk of transmission of SARS-CoV-2 from fomites, (III) infectivity of SARS-CoV-2 on surfaces, (IV) modes of transmission, (V) nosocomial transmission of SARS-CoV-2 from surface environments.

Moreover, the articles were assessed by the contamination risk and were classified by "low", "high", "plausible", and "unlikely" risk. Furthermore, a category was defined as "insufficient evidence". Nine articles out of $24(37.5 \%)$ assessed a low probability of transmission, and four articles out of $24(16.7 \%)$ stated a high transmission probability.

Importantly, seven out of the 24 articles (29.2\%) indicated not having enough evidence to determine the risk of SARS-CoV-2 infection by contaminated surfaces. These findings are summarized in Figure 2, and a detailed review of the risk assessment can be found in Table 1. 


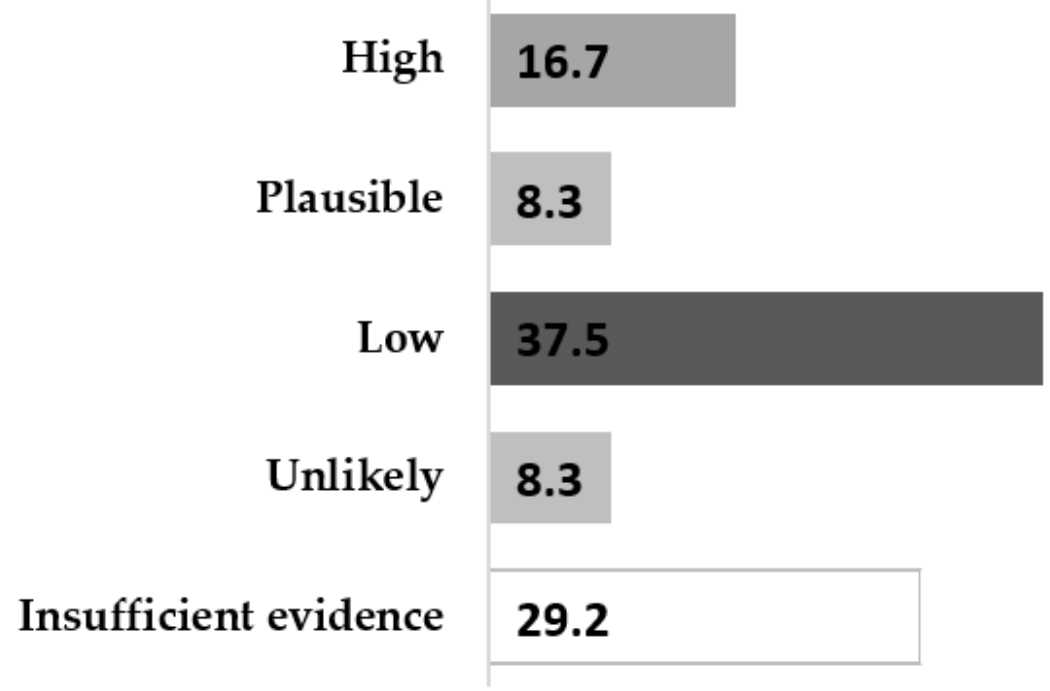

Figure 2. Contamination risk assessment of SARS-CoV-2 with contaminated surfaces (\%).

Table 1. Comments from the reviewed articles regarding the level of risk of SARS-CoV-2 infection through contact with contaminated surfaces.

- “While direct transmission is important, our model suggests fomites can also transmit, which is important for exposures that are not in-person. Therefore, fomite transmission may be an important source of risk." [22]

- " “After reviewing 'Similarities between SARS-CoV-2 and Other Coronaviruses', 'Effect of Media, Temperature, Relative Humidity, UV Irradiation, and Material-Type on SARS-CoV-2 Persistence', the researchers concluded "the virus will persist on high-touch surfaces long enough to spread to new individuals." [23]

High

- "Interpretation of findings for SARS-CoV-2 strongly suggest that the environment can serve as a medium of transmission of SARS-CoV-2, through touch contamination and subsequent self-inoculation of mucous membranes by a non-infected individual coming into contact with a contaminated environmental surface or fomite." [27]

- "Our data showed that SARS-CoV-2 infectivity was remarkably preserved in the presence of proteins, regardless of the type of surface."; "The results showed that moderate protein concentration in droplets markedly increased the infectivity of SARS-CoV-2, suggesting that a pro-tein-rich medium like airway secretions could protect the virus when it is expelled and may enhance its persistence and transmission by contaminated fomites. Accordingly, it is plausible that fomites infected with SARS-CoV-2 play a key role in the indirect transmission of COVID-19." [24]

- "These findings suggest that the hospital environment could potentially be a source of virus spread,

Plausible including among HCWs, patients, and visitors." [25]

- "Our results indicate fomite transmission of SARS-CoV-2 is plausible since the virus can remain viable and infectious on surfaces up to days." [28]

- "The work supports the current perception that contaminated surfaces are not a primary mode of transmission of SARS-CoV-2."; "The risks posed by contact surfaces in 30 communities are low for community infection prevalence rates ranging from $0.2-5 \% . "$ [11]

- $\quad$ "The chance of transmission through inanimate surfaces is very small, and only in instances where an infected person coughs or sneezes on the surface, and someone else touches that surface soon after the

Low cough or sneeze (within 1-2 h)." [19]

- $\quad$ "Findings suggest that environmental contamination leading to SARS-CoV-2 transmission is unlikely to occur in real-life conditions, provided that standard cleaning procedures and precautions are enforced."; "transmission is unlikely to occur in real-life conditions, provided that standard cleaning procedures and precautions are enforced." [29]

- "The risk of transmission via touching contaminated paper is low." [20] 
Table 1. Cont.

- "The results indicate that at that early time of SARS-CoV-2 outbreak research in Germany the contamination of the domestic environment is negligible during quarantine measured with the current state of the art methods. We could not detect any viral RNA in air samples and only $3.36 \%$ of all fomite samples."; "This study supports the hypothesis that indirect environmental transmission may only play a minor role, which needs clarifications in further studies." [21]

- $\quad$ "Toilet bowl and sink samples were positive, suggesting that viral shedding in stool could be a potential route of transmission." [30]

- $\quad$ "The estimated risk of infection from touching a contaminated surface was low (less than five in 10,000) by quantitative microbial risk assessment, suggesting fomites play a minimal role in SARS-CoV-2 community transmission."; "our results are consistent with fomite-mediated transmission of COVID-19 being possible but likely a secondary pathway." [31]

- $\quad$ "Despite prolonged viability of SARS-CoV-2 under laboratory-controlled conditions, uncultivable viral contamination of inanimate surfaces might suggest low feasibility for indirect fomite transmission."; "Aerosol or indirect transmission from inanimate surfaces around hospitalized or quarantined COVID-19 patients is not supported by the data presented in this study" [25].

- "The concentration of viral RNA was low and ranged from $<10$ to 460 genomic copies $/ \mathrm{m} 3$ air. Infectious virus was not recovered from any of the PCR-positive samples analyzed." [26]

- "Data on the transmissibility of coronaviruses from contaminated surfaces to hands were not found"; "The viral load of coronaviruses on inanimate surfaces is not known." [32] Unlikely $\quad$ "Our data suggest that although environmental contamination may occur in real-life conditions, it might
be less extensive than hitherto recognized. Moreover, the inability of the SARS-CoV-2 RNA collected from the CPAP helmet to infect susceptible cell monolayers suggests that recent contamination of plastic surfaces, which apparently maintain SARS-CoV-2 infectivity for several hours, is unlikely to contribute to nosocomial spread." [33]

- $\quad$ "Fomite transmission, i.e., viral dissemination via a material, including a door handgrip, door-bell, or inhalator, also has a critical contribution to the virus spread."; "Survival duration of the COVID-19 causing virus on surfaces is not certainly known" [34]

- " Indirect transmission of COVID-19 has been assumed to be possible via fomites although direct evidence is currently not available."; "The virus has been detected in hospital and household settings but detection of viral RNA on surfaces does not provide any information about viral infectivity or viability." [35]

- "The infectious dose of SARS-CoV-2, namely the average number of viral particles required to establish an infection for COVID-19 is unknown."; "It is currently unclear what role the surface chemistry plays in viral survival, infectivity, and denaturation, and the role of the local environment is unclear." [36]

Insufficient evidence
- "Fomite transmission would depend on the surface characteristics, which can affect virus survival and can help determine the extent of spread of the disease." [37]

- "Overall, there was an inability to align SARS-CoV-2 contaminated surfaces with survivability data; and also a knowledge gap on fomite contribution to SARS-CoV-2 transmission." [38]

- $\quad$ "Virus detection does not necessarily represent an infectious dose of SARS-CoV-2. Although SARS-CoV-2 may be transmitted via direct and indirect contact by touching contaminated sur-faces or medical equipment, followed by touching mouth, nose, or eyes, it remains unknown what portion of the transmission is attributable to a fomite." [39]

- "The important ways of transmitting the virus are through Droplets, infected hands, and skin-to-skin contact, as well as inanimate surface contact." [40]

\section{Discussion}

This scoping review was performed to evaluate the available literature related to the risks of infection transmission via contaminated surfaces with SARS-CoV-2.

Our research highlights a noticeable variability in the findings of articles assessing the risk of transmission via fomites classified as follows: low or high possibility, unlikeliness, plausibility, or lack of adequate evidence to identify the risks of infection transmitted by fomites.

While previous studies on different microorganisms have demonstrated the existing risk of transmission by contaminated surfaces [13-18], surprisingly, only six out of 24 of the articles had indicated the "plausibility" or high risk of infection via fomites in the case of SARS-CoV-2 contamination. 
We found that $29.2 \%$ of the reviewed articles stated an absence of enough evidence, and most of the articles, i.e., $45.8 \%$, concluded a low probability or unlikeliness. Interestingly, those articles were mostly focused on the following conclusions: (i) the existence of the virus on surfaces does not prevail the risks of infection by the virus, and (ii) there is a lack of information about the infectious dose of SARS-CoV-2 on the surfaces to be transmitted in order to cause infection $[32,35,38,39]$. For instance, "The infectious dose of SARS-CoV-2, namely the average number of viral particles required to establish an infection for COVID19 is unknown" as stated by Xue et al. 2020 [36]. Another rationale observed to support the low probability of transmission of the SARS-CoV-2 via contaminated surfaces is the demonstration that viruses cannot reproduce outside the host, and the observation of the rare occurrence of touching surfaces contaminated with viral loads high enough to be infective and the subsequently touch face membranes such as eyes, or nose [11,39].

In addition, as mentioned by the World Health Organization (WHO), "it is difficult to disentangle the relative contributions of inhaled droplets and contaminated surfaces because people who have come into contact with potentially infectious surfaces have generally also been in close contact with infected individuals".

Moreover, there are differences between real-life and laboratory conditions, which lead to lower risks in the real living environment, especially when hygiene protocols and cleaning procedures are followed [11,29,33].

From another standpoint, the long persistence of the virus on surfaces might cause a high possibility of infection via contaminated surfaces [24,28]. In one reviewed study focused on hospital settings, with the assumption made that the concentration of the virus might be more important, fomites were identified as potential sources of the virus spread [25]. On the contrary, three other studies performed in the same settings concluded that the risk of transmission and infection is not high [21,26,31].

Interestingly although this scoping review aimed to identify specifically the risk of infection via fomites, we could observe debates about the duration of the virus presence on different surfaces and the environmental effects on it. For instance, "in laboratorycontrolled conditions and at the ambient temperature, SARS-CoV-2 lost its infectivity completely by day 4 " [31].

We also consider it crucial to mention that studies demonstrated that higher temperature, sunlight, and UV radiation highly lead to the inactivation of SARS-CoV-2 [23,37]. Those are important factors to be understood in the real-life context of the SARS-CoV-2 life cycle. In addition, studies demonstrated that the RNA of common viruses, such as SARS-CoV-2, Influenza, and MERS-CoV, can persist on surfaces for days after they have lost their infectivity [23], therefore, detecting viral RNA on surfaces cannot solely provide information about the infectivity of the virus [35]. Thus, such information has to be taken with the necessary scrutiny to avoid potential incomplete conclusions about the probability of getting infected via fomites in real-life conditions.

\section{Conclusions}

Given the date of the last search performed, articles published after 10 February 2021, were not integrated in our review. Some recent publications on that topic were found, confirming the relevance of this topic.

Conclusively, the main outcome of this scoping review is that the risk of SARS-CoV-2 infection via contaminated surfaces was assessed as low in the majority of the reviewed articles. Further evaluation of the risk of the virus transmission by fomites and adequate information on its infectivity via contaminated surfaces in real-life conditions are essential. Those investigations would participate in setting more efficient guidelines to limit the spread of the SARS-CoV-2. Until more evidence on the risk of the virus transmission by fomites in real-life situations can be gathered, it remains important to follow disinfection guidelines and, most importantly, respect physical distancing and the use of masks to limit the propagation of the COVID-19 pandemic. Finally, the authors acknowledge that scientific data and related issues regarding the SARS-CoV-2 virus and potential variants evolve 
rapidly, but at the time of the research, no sufficient data was available mentioning possible variants and fomites transmission. Therefore, it appears key to take into consideration those elements in future research.

Author Contributions: M.M. contributed to the implementation of the research, analysis of the results, and writing of the manuscript. A.B.-A. contributed to the validation, review of the overall manuscript. A.L. reviewed the content of the manuscript. A.F. designed, directed, and supervised the project. All authors have read and agreed to the published version of the manuscript.

Funding: This research received no external funding.

Conflicts of Interest: The authors stated that they had no interests, which might be perceived as posing a conflict of interest, or bias.

\section{Appendix A}

Table A1. Detailed information of review articles.

\begin{tabular}{|c|c|c|c|c|c|c|}
\hline No & Reference & Publication Date & Study Location & Type of Record & $\begin{array}{c}\text { Contamination } \\
\text { Risk Assessment }\end{array}$ & Study Setting \\
\hline 1 & Mondelli et al. [29] & 2020 Sep & NA & Correspondence & Low & NA \\
\hline 2 & Goldman [19] & 2020 July & NA & Comment & Low & NA \\
\hline 3 & Kampf [32] & $2020 \mathrm{Feb}$ & NA & Original article & Unlikely & NA \\
\hline 4 & $\begin{array}{l}\text { Hoseinzadeh et al. } \\
\text { [34] }\end{array}$ & 2020 July & NA & Review article & $\begin{array}{l}\text { Not enough } \\
\text { evidence }\end{array}$ & NA \\
\hline 5 & Kampf et al. [35] & 2020 Sep & NA & Review article & $\begin{array}{l}\text { Not enough } \\
\text { evidence }\end{array}$ & NA \\
\hline 6 & Bueckert et al. [23] & 2020 Nov & NA & Review article & High & NA \\
\hline 7 & Xue et al. [36] & 2020 Nov & NA & Review article & $\begin{array}{l}\text { Not enough } \\
\text { evidence }\end{array}$ & NA \\
\hline 8 & Wathore et al. [37] & 2020 Aug & NA & Review article & $\begin{array}{l}\text { Not enough } \\
\text { evidence }\end{array}$ & NA \\
\hline 9 & Bedrosian et al. [38] & 2020 Nov & NA & Review article & $\begin{array}{l}\text { Not enough } \\
\text { evidence }\end{array}$ & NA \\
\hline 10 & Pitol and Julian [11] & 2020 Nov & Switzerland & $\begin{array}{l}\text { Original article } \\
\text { (Pre-Print) }\end{array}$ & Low & $\begin{array}{l}\text { Community } \\
\text { setting }\end{array}$ \\
\hline 11 & Kraay et al. [22] & 2020 Aug & US & $\begin{array}{l}\text { Original article } \\
\text { (Pre-Print) }\end{array}$ & High & $\begin{array}{l}\text { Schools } \\
\text { Offices }\end{array}$ \\
\hline 12 & Ong et al. [27] & 2020 July & NA & Review article & High & NA \\
\hline 13 & Kanamori [39] & 2021 Jan & NA & Letter to editor & $\begin{array}{l}\text { Not enough } \\
\text { evidence }\end{array}$ & NA \\
\hline 14 & Eslami and Jalili [40] & 2020 May & NA & Review article & $\begin{array}{l}\text { Not enough } \\
\text { evidence }\end{array}$ & NA \\
\hline 15 & Pastorino et al. [24] & 2020 Sep & France & Research Letter & High & Laboratory setting \\
\hline 16 & $\begin{array}{c}\text { Van Doremalen et al. } \\
\text { [28] }\end{array}$ & 2020 April & US & Correspondence & Plausible & NA \\
\hline 17 & Colaneri et al. [33] & 2020 May & Italy & Original article & Unlikely & $\begin{array}{c}\text { Hospital } \\
\text { (emergency unit) }\end{array}$ \\
\hline 18 & Ren et al. [20] & 2020 April & NA & Review article & Low & NA \\
\hline 19 & Döhla et al. [41] & 2020 Jun & Germany & $\begin{array}{l}\text { Original article } \\
\text { (Pre-print) }\end{array}$ & Low & Quarantinehousehold \\
\hline 20 & Ong et al. [21] & March 2020 & Singapore & Original article & Low & Hospital \\
\hline 21 & Harvey et al. [30] & $2020 \mathrm{Dec}$ & U.S.A & Original article & Low & $\begin{array}{l}\text { Community } \\
\text { setting }\end{array}$ \\
\hline 22 & Ben-Shmuel [31] & 2020 Dec & Israel & Original article & Low & $\begin{array}{l}\text { Hospital: Isolation unit } \\
\text { Quarantine hotel }\end{array}$ \\
\hline
\end{tabular}


Table A1. Cont.

\begin{tabular}{ccccccc}
\hline No & Reference & Publication Date & Study Location & Type of Record & $\begin{array}{c}\text { Contamination } \\
\text { Risk Assessment }\end{array}$ & Study Setting \\
\hline 23 & Ye et al. [25] & April 2020 & China (Wuhan) & Original article & Plausible & Hospital \\
\hline 24 & Moore et al. [26] & 2020 Nov & England & Original article & Low & Hospital \\
\hline
\end{tabular}

Table A2. Key findings of review articles.

\begin{tabular}{|c|c|c|c|}
\hline No & Reference & Main Topic & Key Findings \\
\hline 1 & [29] & $\begin{array}{l}\text { Risk of transmission of } \\
\text { SARS-CoV-2 from fomites }\end{array}$ & $\begin{array}{c}\text { "Findings suggest that environmental contamination leading to } \\
\text { SARS-CoV-2 transmission is unlikely to occur in real-life conditions, } \\
\text { provided that standard cleaning procedures and precautions } \\
\text { are enforced." }\end{array}$ \\
\hline 2 & [19] & $\begin{array}{l}\text { Risk of transmission of } \\
\text { SARS-CoV-2 from fomites }\end{array}$ & $\begin{array}{c}\text { "The chance of transmission through inanimate surfaces is very small, } \\
\text { and only in instances where an infected person coughs or sneezes on } \\
\text { the surface, and someone else touches that surface soon after the cough } \\
\text { or sneeze (within 1-2 h)." }\end{array}$ \\
\hline 3 & [32] & $\begin{array}{c}\text { Persistence of coronaviruses } \\
\text { on inanimate surfaces }\end{array}$ & $\begin{array}{c}\text { "Data on the transmissibility of coronaviruses from contaminated } \\
\text { surfaces to hands were not found" "The viral load of coronaviruses on } \\
\text { inanimate surfaces is not known." }\end{array}$ \\
\hline 4 & [34] & $\begin{array}{c}\text { Modes of } \\
\text { SARS-CoV-2 transmission }\end{array}$ & $\begin{array}{l}\text { "Fomite transmission, i.e., viral dissemination via a material, including } \\
\text { a door handgrip, door-bell, or inhalator, also has a critical contribution } \\
\text { to the virus spread." "Survival duration of the COVID-19 causing virus } \\
\text { on surfaces is not certainly known" }\end{array}$ \\
\hline 5 & [35] & $\begin{array}{c}\text { Modes of } \\
\text { SARS-CoV-2 transmission }\end{array}$ & $\begin{array}{l}\text { "Indirect transmission of COVID- } 19 \text { has been assumed to be possible } \\
\text { via fomites although direct evidence is currently not available." "The } \\
\text { virus has been detected in hospital and household settings but } \\
\text { detection of viral RNA on surfaces does not provide any information } \\
\text { about viral infectivity or viability" }\end{array}$ \\
\hline 6 & [23] & $\begin{array}{l}\text { Infectivity of SARS-CoV-2 } \\
\text { on surfaces }\end{array}$ & $\begin{array}{l}\text { “After reviewing 'Similarities between SARS-CoV-2 and Other } \\
\text { Coronaviruses', 'Effect of Media, Temperature, Relative Humidity, UV } \\
\text { Irradiation, and Material-Type on SARS-CoV-2 Persistence', the } \\
\text { researchers concluded "the virus will persist on high-touch surfaces } \\
\text { long enough to spread to new individuals" }\end{array}$ \\
\hline 7 & [36] & $\begin{array}{l}\text { Infectivity of SARS-CoV-2 } \\
\text { on surfaces }\end{array}$ & $\begin{array}{l}\text { "The infectious dose of SARS-CoV-2, namely the average number of } \\
\text { viral particles required to establish an infection for COVID-19 is } \\
\text { unknown". "It is currently unclear what role the surface chemistry } \\
\text { plays in viral survival, infectivity, and denaturation, and the role of the } \\
\text { local environment is unclear." }\end{array}$ \\
\hline 8 & [37] & $\begin{array}{c}\text { Modes of } \\
\text { SARS-CoV-2 transmission }\end{array}$ & $\begin{array}{c}\text { "Fomite transmission would depend on the surface characteristics, } \\
\text { which can affect virus survival and can help determine extent of spread } \\
\text { of the disease." }\end{array}$ \\
\hline 9 & [38] & $\begin{array}{l}\text { Risk of infection by } \\
\text { fomites transmission }\end{array}$ & $\begin{array}{l}\text { "Overall, there was an inability to align SARS-CoV-2 contaminated } \\
\text { surfaces with survivability data; and also, a knowledge gap on fomite } \\
\text { contribution to SARS-COV-2 transmission." }\end{array}$ \\
\hline 10 & [11] & $\begin{array}{l}\text { Risk of infection by } \\
\text { fomites transmission }\end{array}$ & $\begin{array}{l}\text { "The work supports the current perception that contaminated surfaces } \\
\text { are not a primary mode of transmission of SARS-CoV-2". "The risks } \\
\text { posed by contacting surfaces in } 30 \text { communities are low for community } \\
\text { infection prevalence rates ranging from } 0.2-5 \% . "\end{array}$ \\
\hline 11 & [22] & $\begin{array}{l}\text { Risk of infection by } \\
\text { fomites transmission }\end{array}$ & $\begin{array}{c}\text { "While direct transmission is important, our model suggests fomites } \\
\text { can also transmit, which is important for exposures that are not } \\
\text { in-person. Therefore, fomite transmission may be an important source } \\
\text { of risk" }\end{array}$ \\
\hline
\end{tabular}


Table A2. Cont.

\begin{tabular}{|c|c|c|c|}
\hline No & Reference & Main Topic & Key Findings \\
\hline 12 & [27] & $\begin{array}{l}\text { Modes of the virus } \\
\text { transmission }\end{array}$ & $\begin{array}{l}\text { "Interpretation of findings for SARS-CoV-2 strongly suggest that the } \\
\text { environment can serve as a medium of transmission of SARS-CoV-2, } \\
\text { through touch contamination and subsequent self-inoculation of } \\
\text { mucous membranes by a non-infected individual coming into contact } \\
\text { with a contaminated environmental surface or fomite." }\end{array}$ \\
\hline 13 & [39] & $\begin{array}{l}\text { Risk of infection by fomites } \\
\text { transmission }\end{array}$ & $\begin{array}{l}\text { "Virus detection does not necessarily represent an infectious dose of } \\
\text { SARSCoV-2. Although SARS-CoV-2 may be transmitted via direct and } \\
\text { indirect contact by touching contaminated surfaces or medical } \\
\text { equipment, followed by touching mouth, nose, or eyes, it remains } \\
\text { unknown what portion of transmission is attributable to a fomite." }\end{array}$ \\
\hline 14 & [40] & $\begin{array}{l}\text { Modes of the virus } \\
\text { transmission }\end{array}$ & $\begin{array}{c}\text { "The important ways of transmitting the virus are through Droplets, } \\
\text { infected hands, and skin-to-skin contact, as well as inanimate } \\
\text { surface contact" }\end{array}$ \\
\hline 15 & [24] & $\begin{array}{l}\text { Infectivity of SARS-CoV-2 on } \\
\text { surfaces }\end{array}$ & $\begin{array}{l}\text { "Our data showed that SARS-CoV-2 infectivity was remarkably } \\
\text { preserved in the presence of proteins, regardless of the type of surface." } \\
\text { "The results showed that a moderate protein concentration in droplets } \\
\text { markedly increased the infectivity of SARS-CoV-2, suggesting that a } \\
\text { protein-rich medium like airway secretions could protect the virus } \\
\text { when it is expelled and may enhance its persistence and transmission } \\
\text { by contaminated fomites. Accordingly, it is plausible that fomites } \\
\text { infected with SARS-CoV-2 play a key role in the indirect transmission } \\
\text { of COVID-19. }\end{array}$ \\
\hline 16 & [28] & $\begin{array}{l}\text { Infectivity of SARS-CoV-2 on } \\
\text { surfaces }\end{array}$ & $\begin{array}{l}\text { "Our results indicate fomite transmission of SARS-CoV-2 is plausible, } \\
\text { since the virus can remain viable and infectious on surfaces up } \\
\text { to days." }\end{array}$ \\
\hline 17 & [33] & $\begin{array}{l}\text { Risk of infection by fomites } \\
\text { transmission }\end{array}$ & $\begin{array}{l}\text { "Our data suggest that although environmental contamination may } \\
\text { occur in real-life conditions, it might be less extensive than hitherto } \\
\text { recognized. Moreover, the inability of the SARS-CoV-2 RNA collected } \\
\text { from the CPAP helmet to infect susceptible cell monolayers suggests } \\
\text { that recent contamination of plastic surfaces, which apparently } \\
\text { maintain SARS-CoV-2 infectivity for several hours, is unlikely to } \\
\text { contribute to nosocomial spread." }\end{array}$ \\
\hline 18 & [20] & $\begin{array}{l}\text { Risk of infection by fomites } \\
\text { transmission }\end{array}$ & "The risk of transmission via touching contaminated paper is low." \\
\hline 19 & [41] & $\begin{array}{l}\text { Risk of infection by fomites } \\
\text { transmission }\end{array}$ & $\begin{array}{l}\text { "The results indicate that at that early time of SARS-CoV-2 outbreak } \\
\text { research in Germany the contamination of the domestic environment is } \\
\text { negligible during quarantine measured with the current state of the art } \\
\text { methods. We could not detect any viral RNA in air samples and only } \\
3.36 \% \text { of all fomite samples." "This study supports the hypothesis that } \\
\text { indirect environmental transmission may only play a minor role, which } \\
\text { needs clarifications in further studies." }\end{array}$ \\
\hline 20 & [21] & $\begin{array}{l}\text { Nosocomial transmission of } \\
\text { SARS-CoV-2 from surface } \\
\text { environmental }\end{array}$ & $\begin{array}{l}\text { "Toilet bowl and sink samples were positive, suggesting that viral } \\
\text { shedding in stool could be a potential route of transmission" }\end{array}$ \\
\hline 21 & [30] & $\begin{array}{l}\text { Risk of infection by fomites } \\
\text { transmission }\end{array}$ & $\begin{array}{l}\text { "The estimated risk of infection from touching a contaminated surface } \\
\text { was low (less than } 5 \text { in 10,000) by quantitative microbial risk } \\
\text { assessment, suggesting fomites play a minimal role in SARS-CoV-2 } \\
\text { community transmission." "our results are consistent with } \\
\text { fomite-mediated transmission of COVID-19 being possible but likely a } \\
\text { secondary pathway" }\end{array}$ \\
\hline
\end{tabular}


Table A2. Cont.

\begin{tabular}{|c|c|c|c|}
\hline No & Reference & Main Topic & Key Findings \\
\hline 22 & [31] & $\begin{array}{l}\text { Infectivity of SARS-CoV-2 } \\
\text { on surfaces }\end{array}$ & $\begin{array}{l}\text { "Despite prolonged viability of SARS-CoV-2 under } \\
\text { laboratory-controlled conditions, uncultivable viral contamination of } \\
\text { inanimate surfaces might suggest low feasibility for indirect fomite } \\
\text { transmission. "Aerosol or indirect transmission from inanimate } \\
\text { surfaces around hospitalized or quarantined COVID-19 patients is not } \\
\text { supported by the data presented in this study." }\end{array}$ \\
\hline 23 & [25] & $\begin{array}{l}\text { Contamination assessment of } \\
\text { and by surfaces in } \\
\text { hospital settings }\end{array}$ & $\begin{array}{l}\text { "These findings suggest that the hospital environment could } \\
\text { potentially be a source of virus spread, including among HCWs, } \\
\text { patients, and visitors" }\end{array}$ \\
\hline 24 & [26] & $\begin{array}{l}\text { Nosocomial transmission of } \\
\text { SARS-CoV-2 from } \\
\text { surface environmental }\end{array}$ & $\begin{array}{c}\text { "The concentration of viral RNA was low and ranged from }<10 \text { to } 460 \\
\text { genomic copies / m3 air. Infectious virus was not recovered from any of } \\
\text { the PCR-positive samples analyzed." }\end{array}$ \\
\hline
\end{tabular}

Table A3. Recommendations and limitations of review articles.

\begin{tabular}{|c|c|c|c|}
\hline No & Reference & Main Topic & Gaps/Limitations/Recommendations for Further Studies \\
\hline 1 & [29] & $\begin{array}{l}\text { Risk of transmission of } \\
\text { SARS-CoV-2 from fomites }\end{array}$ & Not Provided \\
\hline 2 & [19] & $\begin{array}{l}\text { Risk of transmission of } \\
\text { SARS-CoV-2 from fomites }\end{array}$ & $\begin{array}{l}\text { "None of these studies (which have been checked by the author) present } \\
\text { scenarios akin to real-life situations." }\end{array}$ \\
\hline 3 & [32] & $\begin{array}{l}\text { Persistence of coronaviruses } \\
\text { on inanimate surfaces }\end{array}$ & Not Provided \\
\hline 4 & [34] & $\begin{array}{c}\text { Modes of } \\
\text { SARS-CoV-2 transmission }\end{array}$ & Not Provided \\
\hline 5 & [35] & $\begin{array}{c}\text { Modes of } \\
\text { SARS-CoV-2 transmission }\end{array}$ & $\begin{array}{l}\text { "It has to be mentioned that in most studies only PCR was per-formed for } \\
\text { RNA. But detection of viral RNA on surfaces does not provide any } \\
\text { information about viral infectivity or viability" }\end{array}$ \\
\hline 6 & [23] & $\begin{array}{l}\text { Infectivity of SARS-CoV-2 } \\
\text { on surfaces }\end{array}$ & $\begin{array}{l}\text { "Each experiment had a specific lower limit of detection (LOD) at which } \\
\text { infectious virus could not be discerned, and distinct sampling points } \\
\text { which influenced data. Consequently, the recorded durations of viability } \\
\text { are inexact and presented as a range in this review. Studies often failed to } \\
\text { report the LOD and/or choice of sampling points, so the applicability of } \\
\text { their data is questionable. There are no available data on the } \\
\text { transmissibility of coronaviruses from inoculated surfaces to hands." }\end{array}$ \\
\hline 7 & [36] & $\begin{array}{l}\text { Infectivity of SARS-CoV-2 } \\
\text { on surfaces }\end{array}$ & $\begin{array}{l}\text { "A systematic study on the lifetime of infectious viruses on a range of } \\
\text { existing polymers under ambient conditions would be useful for those } \\
\text { choosing which personal protective equipment to use. The theoretical basis } \\
\text { for describing viral particle interactions at synthetic surfaces is not } \\
\text { well developed." }\end{array}$ \\
\hline 8 & [37] & $\begin{array}{c}\text { Modes of } \\
\text { SARS-CoV-2 transmission }\end{array}$ & $\begin{array}{l}\text { "Nature of the role played by Particulate Matter should be thoroughly } \\
\text { examined so as to understand its efficacy in aiding or reducing the } \\
\text { transmission and survival of these viruses. The lack of information on } \\
\text { particulate matter effect prevents complete understanding on the stability } \\
\text { of coronavirus on particulate matter and PM-contaminated common } \\
\text { surfaces. it is high time that the effect of confounding factors such as } \\
\text { composition of particulate matter, should be explored in detail to } \\
\text { understand the chances of real-life survivability and transmissibility of } \\
\text { viruses such as SARS-CoV-2." }\end{array}$ \\
\hline
\end{tabular}


Table A3. Cont.

\begin{tabular}{lll}
\hline No Reference & Main Topic & Gaps/Limitations/Recommendations for Further Studies \\
\hline "Pre-prints were included in review, bias was not assessed beyond noting \\
preprint percentage, and after completing the review we (based on \\
information available) determined to focus the review on surface \\
contamination, stability, and disinfection. Also, no data was found in this \\
review that suggests the actual likelihood of contracting COVID-19 via \\
fomites; in subsequent systematic reviews, it is recommended to include \\
patient case studies to assess potential fomite base transmission across \\
settings. We do not feel these limitations impact "The model is based on \\
data of SARS-CoV and Murine hepatitis virus (MHV-1) infection in mice \\
by intranasal administration. Extrapolating the model from mice to people \\
and from MHV-1 and SARS-CoV to SARS-CoV-2, introduces uncertainty in \\
infection risk estimates, but we did not consider this here. An additional \\
fomites transmission \\
limitation is that the dose-response relationship was determined using \\
virus as measured in units of Plaque Forming Units (PFU) and therefore a \\
ratio of genome copies to PFU is needed. Model parameters used for virus \\
transfer and decay rates are determined experimentally in laboratory \\
conditions and could be different in environmental conditions. Also, \\
prevalence rates modeled here are assumed to correspond directly with the \\
percent of people who are infected and contact the surface with a hand \\
contaminated by coughing. In reality, an unknown fraction of infected \\
people would likely either: 1) stay at home, or 2) not cough directly on \\
their hand." the results presented herein."
\end{tabular}

"The model is based on data of SARS-CoV and Murine hepatitis virus (MHV-1) infection in mice by intranasal administration. Extrapolating the model from mice to people and from MHV-1 and SARS-CoV to SARS-CoV-2, introduces uncertainty in infection risk estimates, but we did not consider this here. An additional limitation is that the dose-response relationship was determined using virus as measured in units of Plaque Forming Units (PFU) and therefore a ratio of genome copies to PFU is needed. Model parameters used for virus transfer and decay rates are determined experimentally in laboratory conditions and could be different in environmental conditions. Also, prevalence rates modeled here are assumed to correspond directly with the percent of people who are infected and contact the surface with a hand contaminated by coughing. In reality, an unknown fraction of infected people would likely either: 1) stay at home, or 2) not cough directly on their hand."

\begin{tabular}{|c|c|c|c|}
\hline 11 & [22] & $\begin{array}{l}\text { Risk of infection by } \\
\text { fomites transmission }\end{array}$ & Not provided \\
\hline 12 & [27] & $\begin{array}{l}\text { Modes of the virus } \\
\text { transmission }\end{array}$ & $\begin{array}{l}\text { "Further studies to clarify the extent and relative importance of each of } \\
\text { these transmission routes, as well as the patient, disease and environmental } \\
\text { factors that affect each medium, are urgently needed to allow policymakers } \\
\text { to risk-stratify and tailor infection control recommendations." }\end{array}$ \\
\hline 13 & [29] & $\begin{array}{l}\text { Risk of infection by fomites } \\
\text { transmission }\end{array}$ & $\begin{array}{l}\text { "Indicating the necessity of further studies on survival and contamination } \\
\text { as well as clinical evidence on fomite transmission" }\end{array}$ \\
\hline 14 & [40] & $\begin{array}{l}\text { Modes of the } \\
\text { virus transmission }\end{array}$ & Not provided \\
\hline 15 & [24] & $\begin{array}{l}\text { Infectivity of SARS-CoV-2 } \\
\text { on surfaces }\end{array}$ & Not provided \\
\hline 16 & [28] & $\begin{array}{c}\text { Infectivity of SARS-CoV-2 } \\
\text { on surfaces }\end{array}$ & Not provided \\
\hline 17 & [33] & $\begin{array}{l}\text { Risk of infection by } \\
\text { fomites transmission }\end{array}$ & $\begin{array}{l}\text { "The timing of swabbing, which was relatively close to the cleaning } \\
\text { procedures and the effectiveness of flocked swabbing for environmental } \\
\text { sampling. Sample collection from the environment was set-up on the basis } \\
\text { of a precise workflow and it cannot apply to surfaces that are not } \\
\text { systematically cleaned, e.g., computer keyboards, telephones, } \\
\text { multi-parameter monitors, infusion pumps, etc. to cite but a few." }\end{array}$ \\
\hline
\end{tabular}


Table A3. Cont.

\begin{tabular}{|c|c|c|c|}
\hline $\begin{array}{l}\text { No } \\
18\end{array}$ & $\begin{array}{c}\text { Reference } \\
\text { [20] }\end{array}$ & $\begin{array}{l}\text { Main Topic } \\
\text { Risk of infection by } \\
\text { fomites transmission }\end{array}$ & $\begin{array}{l}\text { Gaps/Limitations/Recommendations for Further Studies } \\
\text { Not provided }\end{array}$ \\
\hline 19 & [41] & $\begin{array}{l}\text { Risk of infection by fomites } \\
\text { transmission }\end{array}$ & $\begin{array}{l}\text { "It should be noted that these data were generated under laboratory } \\
\text { conditions. It can be assumed that households in quarantine have a } \\
\text { cleaning regime, but even under these conditions viral RNA could be } \\
\text { found on fomites in the households. A further characterization of different } \\
\text { cleaning systems (frequency, cleaning agents, ventilation of rooms, etc.) } \\
\text { would be necessary; however, this effect could only be validly estimated in } \\
\text { observational studies, since a large bias towards social desirability can be } \\
280 \text { expected in surveys" }\end{array}$ \\
\hline 20 & [21] & $\begin{array}{l}\text { Nosocomial transmission of } \\
\text { SARS-CoV-2 from } \\
\text { surface environmental }\end{array}$ & $\begin{array}{l}\text { "This study has several limitations. First, viral culture was not done to } \\
\text { demonstrate viability. Second, due to operational limitations during an } \\
\text { outbreak, methodology was inconsistent and sample size was small. } \\
\text { Further studies are required to confirm these preliminary results." }\end{array}$ \\
\hline 21 & [30] & $\begin{array}{l}\text { Risk of infection by } \\
\text { fomites transmission }\end{array}$ & $\begin{array}{l}\text { "Uncertainty in key QMRA model parameters could lead to an } \\
\text { overestimate of the risk." the ratio of RNA to viable virus in clinical } \\
\text { samples may be different than this ratio in environmental surface samples. } \\
\text { We did not attempt to culture live virus from any of our surface samples } \\
\text { and therefore cannot determine the viability or infectivity of the } \\
\text { SARS-CoV-2 detected in our samples. Future work is needed to confirm } \\
\text { the relationship between SARS-CoV-2 RNA concentrations and viable } \\
\text { virus on surfaces and to determine if infective SARS-CoV-2 can be } \\
\text { recovered from fomites in community settings." }\end{array}$ \\
\hline
\end{tabular}

"There was a delay between onset of symptoms and the actual sampling in patients' rooms. Therefore, at the time of sampling, these patients might not have shed viable virus, as suggested by studies that showed culturable viruses in respiratory samples up to the 8th or 9th day of illness. For that reason, we have noted new patients with recent disease onset in Hospital $\mathrm{A}$ and the quarantine hotel and sampled around them. The CPE assay has $22 \quad[31] \quad \begin{gathered}\text { Infectivity of SARS-CoV-2 } \\ \text { on surfaces }\end{gathered}$ a $10 \mathrm{pfu} / \mathrm{mL}$ limit of detection that is comparable to a CT value of 34 , therefore a very low level of viability cannot be ruled out. Unforeseen technical issues could have compromised viability of the virus after sampling. We addressed this limitation by collecting nearly 100 samples in three separate campaigns and maintaining strict cold storage conditions after sampling and during transport. Moreover, re-culturing of all the negative cultures was performed to overcome any problems of culture adaptation of freshly isolated virus."

"SARS-CoV-2 culture samples were not collected; thus, exact bioburden levels were unable to be determined. No air samples were collected during the investigation. This study focused on hospital surface contamination of SARS-CoV-2 RNAs as a surrogate of exposure to SARS-CoV-2. We were limited in our ability to characterize other exposure factors, such as other exposure routes, frequencies, and duration. A lack of resources also meant that we were unable to conduct a comprehensive exposure study for the HCWs working in the hospital in the midst of the ongoing outbreak."

"When sampling the healthcare environment, many variables can impact the results obtained. This can make interpretation of the data difficult, particularly if a frame of reference is lacking. In this study and to provide context, agar contact plates were used to provide an aerobic bacterial colony count and an indication of surface cleanliness."

\section{References}

1. Lomont, A.; Boubaya, M.; Khamis, W.; Deslandes, A.; Cordel, H.; Seytre, D.; Tandjaoui-Lambiotte, Y. Environmental contamination related to SARS-CoV-2 in ICU patients. ERJ Open Res. 2020, 6, 00595-2020. [CrossRef] [PubMed]

2. Haleem, A.; Javaid, M.; Vaishya, R. Effects of COVID 19 pandemic in daily life. Curr. Med. Res. Pract. 2020, 10, 78-79. [CrossRef] [PubMed] 
3. Donthu, N.; Gustafsson, A. Effects of COVID-19 on business and research. J. Bus. Res. 2020, 117, 284. [CrossRef] [PubMed]

4. Peeri, N.C.; Shrestha, N.; Rahman, M.S.; Zaki, R.; Tan, Z.; Bibi, S.; Baghbanzadeh, M.; Aghamohammadi, N.; Zhang, W.; Haque, U. The SARS, MERS and novel coronavirus (COVID-19) epidemics, the newest and biggest global health threats: What lessons have we learned? Int. J. Epidemiol. 2020, 49, 717-726. [CrossRef] [PubMed]

5. Krishan, K.; Kanchan, T. Aerosol and surface persistence: SARS-CoV-2 versus other coronaviruses. J. Infect. Dev. Ctries. 2020, 14, 748-749. [CrossRef]

6. Ciotti, M.; Ciccozzi, M.; Terrinoni, A.; Jiang, W.-C.; Wang, C.-B.; Bernardini, S. The COVID-19 pandemic. Crit. Rev. Clin. Lab. Sci. 2020, 57, 365-388. [CrossRef]

7. Carraturo, F.; Del Giudice, C.; Morelli, M.; Cerullo, V.; Libralato, G.; Galdiero, E.; Guida, M. Persistence of SARS-CoV-2 in the environment and COVID-19 transmission risk from environmental matrices and surfaces. Environ. Pollut. 2020, $265,115010$. [CrossRef]

8. Castaño, N.; Cordts, S.; Jalil, M.K.; Zhang, K.; Koppaka, S.; Bick, A.; Tang, S.K. Fomite transmission and disinfection strategies for SARS-CoV-2 and related viruses. arXiv 2020. Available online: arXiv.org/abs/2005.11443 (accessed on 15 January 2021).

9. Zhang, R.; Li, Y.; Zhang, A.L.; Wang, Y.; Molina, M.J. Identifying airborne transmission as the dominant route for the spread of COVID-19. Proc. Natl. Acad. Sci. USA 2020, 117, 14857-14863. [CrossRef] [PubMed]

10. Kanamori, H.; Weber, D.J.; Rutala, W.A. The role of the healthcare surface environment in SARS-CoV-2 transmission and potential control measures. Clin. Infect. Dis. 2020, 72, 2052-2061. [CrossRef]

11. Pitol, A.K.; Julian, T.R. Community Transmission of SARS-CoV-2 by Fomites: Risks and Risk Reduction Strategies. medRxiv 2020, 8, 263-269.

12. Lu, C.-W.; Liu, X.-F.; Jia, Z.-F. 2019-nCoV transmission through the ocular surface must not be ignored. Lancet 2020, 395, e39. [CrossRef]

13. Otter, J.A.; Yezli, S.; French, G.L. The Role of Contaminated Surfaces in the Transmission of Nosocomial Pathogens. In Use of Biocidal Surfaces for Reduction of Healthcare Acquired Infections; Springer: Cham, Switzerland, 2014; pp. 27-58.

14. Stephens, B.; Azimi, P.; Thoemmes, M.S.; Heidarinejad, M.; Allen, J.G.; Gilbert, J.A. Microbial exchange via fomites and implications for human health. Curr. Pollut. Rep. 2019, 5, 198-213. [CrossRef]

15. Boone, S.A.; Gerba, C.P. Significance of fomites in the spread of respiratory and enteric viral disease. Appl. Environ. Microbiol. 2007, 73, 1687-1696. [CrossRef] [PubMed]

16. Lei, H.; Li, Y.; Xiao, S.; Yang, X.; Lin, C.; Norris, S.L.; Wei, D.; Hu, Z.; Ji, S. Logistic growth of a surface contamination network and its role in disease spread. Sci. Rep. 2017, 7, 1-10.

17. Rusin, P.; Maxwell, S.; Gerba, C. Comparative surface-to-hand and fingertip-to-mouth transfer efficiency of gram-positive bacteria, gram-negative bacteria, and phage. J. Appl. Microbiol. 2002, 93, 585-592. [CrossRef] [PubMed]

18. Kwok, Y.L.A.; Gralton, J.; McLaws, M.-L. Face touching: A frequent habit that has implications for hand hygiene. Am. J. Infect. Control. 2015, 43, 112-114. [CrossRef] [PubMed]

19. Goldman, E. Exaggerated risk of transmission of COVID-19 by fomites. Lancet Infect. Dis. 2020, 20, 892-893. [CrossRef]

20. Ren, S.-Y.; Wang, W.-B.; Hao, Y.-G.; Zhang, H.-R.; Wang, Z.-C.; Chen, Y.-L.; Gao, R.D. Stability and infectivity of coronaviruses in inanimate environments. World J. Clin. Cases 2020, 8, 1391. [CrossRef]

21. Ong, S.W.X.; Tan, Y.K.; Chia, P.Y.; Lee, T.H.; Ng, O.T.; Wong, M.S.Y.; Marimuthu, K. Air, surface environmental, and personal protective equipment contamination by severe acute respiratory syndrome coronavirus 2 (SARS-CoV-2) from a symptomatic patient. Jama 2020, 323, 1610-1612. [CrossRef] [PubMed]

22. Kraay, A.N.M.; Hayashi, M.A.; Berendes, D.M.; Sobolik, J.S.; Leon, J.S.; Lopman, B.A. Risk of fomite-mediated transmission of SARS-CoV-2 in child daycares, schools, and offices: A modeling study. MedRxiv 2020. [CrossRef]

23. Bueckert, M.; Gupta, R.; Gupta, A.; Garg, M.; Mazumder, A. Infectivity of SARS-CoV-2 and Other Coronaviruses on Dry Surfaces: Potential for Indirect Transmission. Materials 2020, 13, 5211. [CrossRef]

24. Pastorino, B.; Touret, F.; Gilles, M.; de Lamballerie, X.; Charrel, R.N. Prolonged infectivity of SARS-CoV-2 in fomites. Emerg. Infect. Dis. 2020, 26, 2256. [CrossRef] [PubMed]

25. Ye, G.; Lin, H.; Chen, S.; Wang, S.; Zeng, Z.; Wang, W.; Wang, X. Environmental contamination of SARS-CoV-2 in healthcare premises. J. Infect. 2020, 81, e1-e5. [CrossRef] [PubMed]

26. Moore, G.; Rickard, H.; Stevenson, D.; Aranega-Bou, P.; Pitman, J.; Crook, A.; Bennett, A. Detection of SARS-CoV-2 within the healthcare environment: A multi-centre study conducted during the first wave of the COVID-19 outbreak in England. J. Hosp. Infect. 2021, 108, 189-196. [CrossRef] [PubMed]

27. Ong, S.W.X.; Coleman, K.K.; Chia, P.Y.; Thoon, K.C.; Pada, S.; Venkatachalam, I.; Marimuthu, K. Transmission modes of severe acute respiratory syndrome coronavirus 2 and implications on infection control: A review. Singap. Med. J. 2020, 1, 21. [CrossRef]

28. Van Doremalen, N.; Bushmaker, T.; Morris, D.H.; Holbrook, M.G.; Gamble, A.; Williamson, B.N.; Munster, V.J. Aerosol and surface stability of SARS-CoV-2 as compared with SARS-CoV-1. N. Engl. J. Med. 2020, 382, 1564-1567. [CrossRef]

29. Mondelli, M.U.; Colaneri, M.; Seminari, E.M.; Baldanti, F.; Bruno, R. Low risk of SARS-CoV-2 transmission by fomites in real-life conditions. Lancet Infect. Dis. 2020, 21, e112. [CrossRef]

30. Harvey, A.P.; Fuhrmeister, E.R.; Cantrell, M.E.; Pitol, A.K.; Swarthout, J.M.; Powers, J.E.; Pickering, A.J. Longitudinal monitoring of SARS-CoV-2 RNA on high-touch surfaces in a community setting. Environ. Sci. Technol. Lett. 2020, 8, 168-175. [CrossRef] 
31. Ben-Shmuel, A.; Brosh-Nissimov, T.; Glinert, I.; Bar-David, E.; Sittner, A.; Poni, R.; Weiss, S. Detection and infectivity potential of severe acute respiratory syndrome coronavirus 2 (SARS-CoV-2) environmental contamination in isolation units and quarantine facilities. Clin. Microbiol. Infect. 2020, 26, 1658-1662. [CrossRef]

32. Kampf, G. Potential role of inanimate surfaces for the spread of coronaviruses and their inactivation with disinfectant agents. Infect. Prev. Pract. 2020, 2, 100044. [CrossRef]

33. Colaneri, M.; Seminari, E.; Novati, S.; Asperges, E.; Biscarini, S.; Piralla, A.; Vecchia, M. Severe acute respiratory syndrome coronavirus 2 RNA contamination of inanimate surfaces and virus viability in a health care emergency unit. Clin. Microbiol. Infect. 2020, 26, 1094.e1-1094.e5. [CrossRef]

34. Hoseinzadeh, E.; Javan, S.; Farzadkia, M.; Mohammadi, F.; Hossini, H.; Taghavi, M. An updated min-review on environmental route of the SARS-CoV-2 transmission. Ecotoxicol. Environ. Saf. 2020, 202, 111015. [CrossRef] [PubMed]

35. Kampf, G.; Brüggemann, Y.; Kaba, H.E.; Steinmann, J.; Pfaender, S.; Scheithauer, S.; Steinmann, E. Potential sources, modes of transmission and effectiveness of prevention measures against SARS-CoV-2. J. Hosp. Infect. 2020, 106, 678-697. [CrossRef] [PubMed]

36. Xue, X.; Ball, J.K.; Alexander, C.; Alexander, M.R. All surfaces are not equal in contact transmission of SARS-CoV-2. Matter 2020, 3, 1433-1441. [CrossRef] [PubMed]

37. Wathore, R.; Gupta, A.; Bherwani, H.; Labhasetwar, N. Understanding air and water borne transmission and survival of coronavirus: Insights and way forward for SARS-CoV-2. Total Environ. 2020, 749, 141486. [CrossRef] [PubMed]

38. Bedrosian, N.; Mitchell, E.; Rohm, E.; Rothe, M.; Kelly, C.; String, G.; Lantagne, D. A Systematic Review of Surface Contamination, Stability, and Disinfection Data on SARS-CoV-2 (Through July 10, 2020). Environ. Sci. Technol. 2020, 55, 4162-4173. [CrossRef]

39. Kanamori, H. Rethinking environmental contamination and fomite transmission of SARS-CoV-2 in the healthcare. J. Infect. 2021, 82, e17-e18. [CrossRef]

40. Eslami, H.; Jalili, M. The role of environmental factors to transmission of SARS-CoV-2 (COVID-19). Amb Express. 2020, 10, 1-8. [CrossRef]

41. Döhla, M.; Wilbring, G.; Schulte, B.; Kümmerer, B.M.; Diegmann, C.; Sib, E.; Schmithausen, R.M. SARS-CoV-2 in environmental samples of quarantined households. medRxiv 2020. [CrossRef] 